\title{
Environmental Practices of SICs Operators
}

\author{
Zeenat Begam Yusof'1, Mariam Jamaludin² \\ ${ }^{1}$ Kulliyyah of Architecture and Environmental Design, \\ International Islamic University Malaysia, 50728 Kuala Lumpur, Malaysia \\ 2 Faculty of Architecture, Planning and Surveying, \\ Universiti Teknologi MARA, 40000 Shah Alam, Malaysia \\ zeensoni@iium.edu.my
}

\begin{abstract}
The uncontrolled lodging industry usually caused environmental degradation. However, some lodging operators have started to incorporate green practices in their operation. The objectives of this study are to identify green practices of Small Island Chalets (SICS) operators in Kapas and Tioman Island in Malaysia and to determine the differences of the green practices on the both islands. This study had employed case study method using in-depth interview and structured observation. Six case studies were selected. The findings had identified the difference and several green practices of the operators. Therefore, this study provides a platform for another similar study to be conducted.

Keywords: Green practices; Small Island Chalets (SIC); Green practices theories.

eISSN: 2398-4279 @ 2017. The Authors. Published for AMER ABRA by e-International Publishing House, Ltd., UK. This is an open-access article under the CC BY-NC-ND license (http://creativecommons.org/licenses/by-ncnd/4.0/). Peer-review under responsibility of AMER (Association of Malaysian Environment-Behaviour Researchers), ABRA (Association of Behavioural Researchers on Asians) and $c E-B s$ (Centre for EnvironmentBehaviour Studies), Faculty of Architecture, Planning \& Surveying, Universiti Teknologi MARA, Malaysia. https://doi.org/10.21834/ajqol.v2i8.65
\end{abstract}




\subsection{Introduction}

Recently, environmental issues such as global warming and climate change are the essence of the global discussion (Smith \& Perks, 2010). All the countries are affected due to the impacts. Essentially, global warming occurred due the industrialisation age. Several sorts of industries grow like mushrooms, which utilise all kinds of chemicals and natural resources. These industries produce vast amounts of waste and carbon dioxide. Not left behind the tourism sector. Several studies had confirmed that tourism is one of the most resources consumptive industry (Baysan, 2001; Chan \& Wong, 2006; Li, Yang, Liu, \& Zheng, 2014; Mason, 2011; McKercher, 1993).

Tourism industry uses an enormous amount of fresh water and energy (Tang, 2012) and produces a vast amount of waste (Bohdanowicz, 2005). It was approximated a typical hotel can produce an excess of $1 \mathrm{~kg}$ of waste per guest per day, which results of tonnes of waste each month (Bohdanowicz, 2005). Counting at the amount of pollution and waste produced by the lodging industry, it is necessary for this industry to take further action in greening the industry.

Large hospitality enterprises are taking gradual steps in greening the industry. Various types of green rating tools and certifications emerged worldwide. Various studies were conducted in the field of environmental management of lodging industry (A. Enz \& A. Siguaw, 1999; Alonso \& Ogle, 2010; George I \& Andreas C, 2003; Goodman, 2000; MolinaAzorín, Claver-Cortés, Lopez-Gamero, \& Tarí, 2009).

However, studies regarding environmental practices of small lodging enterprises are way behind, particularly in Malaysia. Thus, the objectives of this study are to identify the environmental practices of the Small Island Chalets (SICs) operators and to determine the differences of the environmental practices on the both islands.

\subsection{Literature Review}

Environmental practices have various synonyms terms such as environmentally friendly practices, green approaches, green practices, best practices, green environmental attributes, and sustainable practices. All the terms considered having the similar meaning which is "practices that applied by the operator to save the environment by cutting back or eliminating his operations impacts on the environment" (IHEI, 1993).

\section{Theoretical studies regarding green practices main items generation}

Environmental practices main items generation for the lodging industry was identified from several kinds of literatures. The first literature was Baker (1987) study. Her work offers a renowned framework of lodging industry attributes. The attributes were divided into three areas such as ambience (non-tangible attributes), design (tangible attributes) and social attributes. The example of ambient attributes was heating, ventilation, air conditioning, lighting, acoustics, scent and cleanliness. Where else, the examples of design attributes are 
layout and comfort, aesthetic, architecture, colours and fabrics. Whereas, the examples of social attributes were service personnel and customers (Baker, 1987).

Later, Kreidler Nicole Bieak (2010) has taken on the Bakers service environment attribute frameworks and developed into green service environment framework. This work has produced a valid scale to measure consumers perceived the importance of green environmental attributes within the service environment. Figure 1 shows example of the environmenta attributes in the lodging industry identified by Kreidler.

\begin{tabular}{|l|l|}
\hline \multicolumn{1}{|c|}{ Tangible attributes } & \multicolumn{1}{c|}{ Non-Tangible attributes } \\
\hline Optimization of building footprint & Air quality \\
\hline Use of sun visors & $\begin{array}{l}\text { Optimization of lighting (foot- } \\
\text { candles) }\end{array}$ \\
\hline Living roof & Temperature control \\
\hline Living wall & Use of compact fluorescent bulbs \\
\hline Operable windows & Use of LED lights \\
\hline Sustainably harvested food & Fresh air transfer \\
\hline Fly ash concrete & Optimization of day lighting \\
\hline Recycled stone & Monitoring of temperature \\
\hline Plaster wall surfaces & Recycling of waste \\
\hline Wool carpets & Zoning of interior environments \\
\hline Linoleum & Acoustics barriers \\
\hline Recycles glass tiles & Recycling of cooking oils \\
\hline Bamboo flooring & Monitoring of global footprint \\
\hline Zero VOC paint & Soy based insulation \\
\hline Natural fiber wall & Use of green cleaning products \\
\hline
\end{tabular}

Fig.1: Green practice components of kreidler study (Source: Kreidler,2010)

However, the environmental practices are not limited to what has identified by Kreidler (2010) study. There are many more environmental practices which is categorised under specific areas such as energy and freshwater management, community involvement, pollution prevention, sewage management, toxic waste management, green purchasing policy, bioclimatic design, renewable energy, paperless technology, environmental conservation programs, green transportation and many more (Enz \& A. Siguaw, 1999; Erdogan \& Baris, 2007; Mensah, 2007; Nabiha et al., 2011; Nicholls \& Kang, 2012; Tooman, Sloan, Legrand, \& Fendt, 2009). These areas were usually listed in the green certification and rating tools.

Content analysis of all the literature above, this study has come up with refined environmental practices framework. The framework divided into technical and behavioural solution. The technical solution consists of tangible and non-tangible environmental attributes. Where else the behavioural solution consists of behavioural attributes. 
Figure 2 shows the component of environmental practices framework. This framework has listed 14 main items of environmental practices into physical, ambient and behavioural attributes. The items are used as the basis of this survey

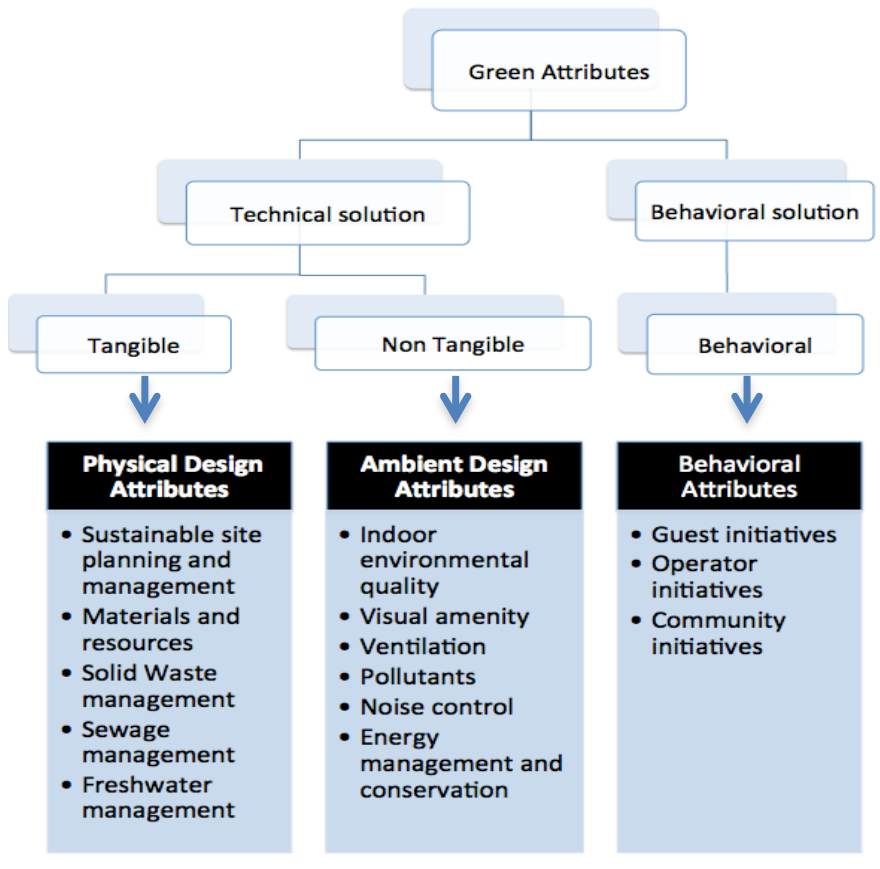

Figure. 2 : Environmental practice framework

(Source: Author)

\subsection{Methodology}

In general, this study applied qualitative research approach using case study method. Indepth interview and structured observation techniques were employed.

\section{Case study description}

This study was conducted on the two Malaysia Marine Park Islands, which are situated along the Eastern side of Peninsular Malaysia. The first island is Kapas Island, which is located in the Terengganu State, and the second island is Tioman Island, which is located in the Pahang State. Kapas Island has nine operating SICs, and Tioman Island has 70 operating SICs. The list of chalets was obtained from various sources such as tripadvisor, 
Journey Malaysia, tourists' blogs, and JPBD Island Booklets. Micro to Small type of SICs was selected for this study. The selection criteria were based on the Standard provided by Malaysia SME Corporation. From the both island only six chalets operators agreed to participate in this study. The chalets are listed in the table below.

Table. 1: List of case studies

\begin{tabular}{ll}
\hline Kapas Island- Terengganu & Tioman Island -Pahang Marine \\
Marine Park & Park \\
(QC) & $(B H C)$ \\
(KBC) & $(A B C)$ \\
$(\mathrm{CLH})$ & $(\mathrm{JR})$ \\
\hline
\end{tabular}

(Source: Author)

\section{Data collection}

Data are collected for this study using in-depth interviews and structured observation checklist. This study is conducted in two phases for each island. In phase one, the researchers conducted general site observation of all the chalets and send participation letter for the study. During general site observation, the existing surrounding environment and general practices are observed in a brief. Later, in phase two in-depth interviews were conducted with the chalet operators using semi-structured interview questions. Structured observation with the aid of the checklist and photographs was conducted after the in-depth interview session.

Tioman Island is a big island, and only one village is chosen for the case study. Within the Tioman Island, Kampong Air Batang was selected as a case study area due to the better accessibility and facilities available. Among the 15 chalets, only four operators decided to participate in this study. Where else, in Kapas Island, only four operators agreed to participate in this study.

\section{Interview questionnaires formulation}

Interview questions were formulated based on the study environmental practices framework above. Interview questions were articulated based on the technical solution only due to the limitation of the time and cost. There are ten main areas of environmental practice. The main areas are listed below.

\section{a) Physical design attributes}

- Sustainable site planning and management

- Materials and resources

- Solid waste management

- Sewage management

- Freshwater management 


\section{b) Ambient design attributes}

- Indoor environmental quality/ ventilation

- Visual amenity element

- Pollutants

- Noise control

- Energy management and conservation

Each main area consists of several sub-questions. Altogether, there are 50 subquestions regarding the environmental practices. The sub-questions are articulated by referring to the several hospitality green rating tools, guidelines and Standard. The sources are ASEAN Tourism Standard (ATS-Green Hotels), Green Building Index (NREB Resort Tool) and Environmental Best Practice Booklet from Department of Marine Park Malaysia. Example of question asked was - Do you apply energy saving or LED lighting in the chalet operation? If yes, Where and what kind energy saving bulb? If No, Why not?

\section{Limitation of the study}

Limitation of this study is time and cost. Expenditure cost in Malaysia Marine Parks Islands is expensive regarding food, boat transportation and accommodations. Therefore, only four days could be spent on the each island based on the researcher personal budget allocation. The second limitation is very few operators agreed to participate in this survey.

\subsection{Results and Discussions}

The results of this study are divided into two sections. In the first section background of the chalets are explained. In the second section environmental practices adopted by the chalet operators are explained.

\section{Background and characteristics of chalet}

It is apparent from the table below, there are several similarities of the background of the SIC operators. One of the similarities is most of the chalets started to operate around the 1980s due to the booming of Malaysia tourism industry. Another similarity is the numbers of the permanent staffs are less than five peoples due to the small capital of the chalet operators. The table also illustrated that different operators provided different services based on their capital and preference. Only four types of services rendered such as accommodation, food, recreation and laundry. 
Table. 2: Background of the case studies chalets

Kapas Island

\begin{tabular}{l|lll}
\hline Name of the chalet & $\boldsymbol{Q C}$ & $\boldsymbol{K} \boldsymbol{B C}$ & $\boldsymbol{K L H}$ \\
\hline Owner age range & $46-55$ & $36-45$ & $56-65$ \\
Education level & Secondary & University & University \\
Operation year & 1986 & 1985 & 1992 \\
No of rooms & 16 chalets & 14 chalets & 8 rooms plus 1 dorm \\
Land size & 1 acres & 1 acres & 1 acres \\
Services provided & Snorkelling and & Accommodation & Accommodation \\
& kayaking & Laundry & Restaurant \\
& Accommodation & & \\
& Restaurant & & \\
& Laundry & 2 & 2 \\
No of permanent staff & 5 & 2 & \\
\hline
\end{tabular}

Tioman Island

\begin{tabular}{l|lll}
\hline Name of the chalet & $\boldsymbol{B H C}$ & $\boldsymbol{A B C}$ & $\boldsymbol{J} \boldsymbol{R}$ \\
\hline Owner age range & Demise & $46-55$ & $46-55$ \\
Education level & Secondary & Secondary & Secondary \\
Operation year & 1998 & 1980 & 1985 \\
No of rooms & 6 chalets & 13 chalets & 12 chalets \\
Land size & 0.5 acres & 2 acres & 3 acres \\
Services provided & Accommodation & Accommodation & Accommodation \\
& Laundry & Restaurant & Restaurant \\
& & Laundry & Laundry \\
& & Snorkelling and diving & Snorkelling and diving \\
No of permanent staff & 2 & 3 & 3 \\
\hline
\end{tabular}

(Source: Author)

\section{Environmental practices of the case studies}

The first objective of this study was to identify the environmental practices of the SICs operators. The practices were identified in Table. 3 below. The finding shows that different operators on the both islands are taking in different environmental practices. For example, regarding solid waste management each of the operators has its own way of reducing the waste such as KBC operator composting its dry and wet waste. Where else, the KLH operator is recycling its aluminium cans and plastic bottles.

However, there are many similar environmental practices adopted by the operators. The similar environmental practices are in the area of materials and resources, sewage management, indoor environmental quality and ventilation, visual amenity, noise control and energy management. Another, finding shows that the chalet design are similar to each other. The examples are chalets built on the stilts, existing terrain and landform is maintained, made of timber and replicating the Malay traditional architecture. The chalets design can be referred at the Figure 3. (a) and (b). 


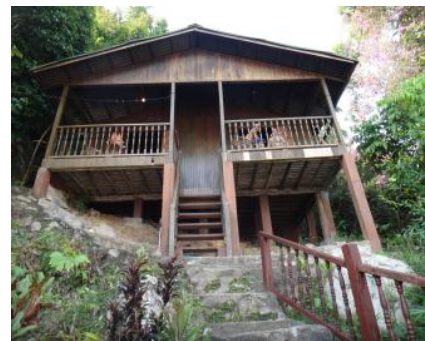

Figure 3(a): Timber chalet at Tioman Island

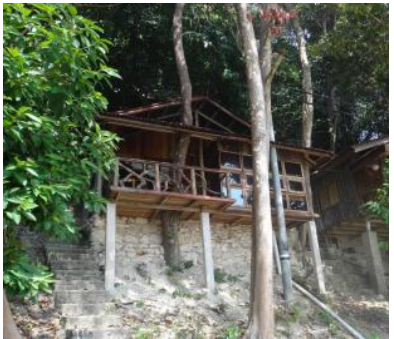

Figure 3(b): Timber chalet at Kapas Island

Other similar green practices were recycling of aluminium cans and cooking oil, use of energy saving bulbs, noise control from cafés and bars, linen drying using sunlight and reuse of products. Whereas, mineral bottles, TV, iron, carpets, fridge and shampoos are not provided in the guest rooms. The omission of this stuff able to save energy, water, waste and freshwater contamination.

The second objective was to determine the differences of the environmental practices on the both islands. There are not many differences in the practices at the both islands. However, only one significant difference was identified. The difference is regarding solid waste management. Kapas Island surrounding environment are cleaner and organised compared to Kampung Air Batang in Tioman Island. The Kapas Island surrounding is clean due to the operators and the Municipal workers clean and collect the waste every day. Besides, many waste bins are located at the beach area.

However, solid waste management on the Tioman Island is less efficient due to the several reasons. The first one is small vessel capacity. Waste vessel only takes in domestic waste, not the construction waste. Therefore, all the construction waste or bulky waste such as broken boats, batteries, oil drums, fridges are thrown on the beach or at the chalet area.

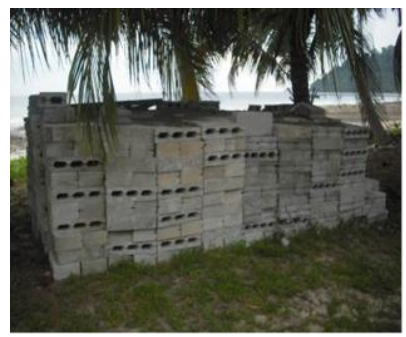

Figure 4(a): unused construction bricks on the beach at Tioman

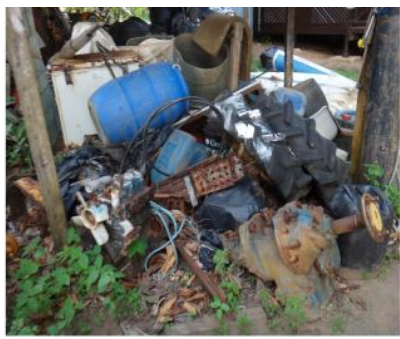

Figure 4(b): bulky waste on the beach at Tioman Island 
The second reason is Tioman Island is a large island with 70 operating chalets and villagers' houses. The amount of waste produced daily is tremendous which makes difficult for a waste vessel to pick up all the waste. Therefore, most of the time waste is left at the collection point at the beach area. Also, recycling or waste bins is not provided at the beach area.

The second difference is Kapas chalet operators are more creative in reducing their solid waste compared to the Tioman Chalet operators. The Kapas operators applied recycle, reuse, reduce and rethink concept in their operation. Some of their interesting environmental practices were listed in the Table. 3 below. The findings revealed that environmental practices decision is closely related to the operator's knowledge and educational background. The three operators interviewed at the Kapas Island are knowledgeable about green practices due to their education level (refer to Table. 2). Whereas, operators interviewed on the Tioman Island shows less understanding regarding green practices due to the lower education level and awareness.

Table. 3: Environmental practices of case studies

\begin{tabular}{|c|c|c|c|c|c|c|}
\hline \multicolumn{4}{|l|}{ Kapas Island } & \multicolumn{3}{|l|}{ Tioman Island } \\
\hline Chalet & QC & KBC & KLH & BHC & $\mathbf{A B C}$ & JR \\
\hline $\begin{array}{l}\text { Sustainable } \\
\text { site planning } \\
\text { and } \\
\text { management }\end{array}$ & $\begin{array}{l}\text { Natural } \\
\text { terrain and } \\
\text { existing trees } \\
\text { maintained } \\
\text { Trees within } \\
\text { chalet } \\
\text { Chalet built } \\
\text { on stilts } \\
\text { Clean env }\end{array}$ & $\begin{array}{l}\text { Big trees } \\
\text { maintained } \\
\text { Herb garden } \\
\text { Plant shrubs } \\
\text { Small scale } \\
\text { Clean benv } \\
\text { Chalet built } \\
\text { on stilts }\end{array}$ & $\begin{array}{l}\text { Big trees } \\
\text { maintained } \\
\text { Chalet } \\
\text { elevated high } \\
\text { Minimum } \\
\text { built up } \\
\text { Clean env } \\
\text { Replant } \\
\text { coconut trees }\end{array}$ & $\begin{array}{l}\text { Natural } \\
\text { terrain and } \\
\text { existing } \\
\text { trees } \\
\text { maintained } \\
\text { Small scale } \\
\text { Clean env } \\
\text { Plant shrubs } \\
\text { Chalet built } \\
\text { on stilts }\end{array}$ & $\begin{array}{l}\text { Plant grass on } \\
\text { the terrain } \\
\text { Fruit trees } \\
\text { Herb garden } \\
\text { Chalet built } \\
\text { on stilts }\end{array}$ & $\begin{array}{l}\text { Natural } \\
\text { ground cover } \\
\text { Terrain } \\
\text { maintained } \\
\text { Chalets built } \\
\text { on stilts } \\
\text { Herb garden }\end{array}$ \\
\hline $\begin{array}{l}\text { Material and } \\
\text { resources }\end{array}$ & $\begin{array}{l}\text { Natural rocks } \\
\text { and tree } \\
\text { columns }\end{array}$ & $\begin{array}{l}\text { Fully timber } \\
\text { construction }\end{array}$ & $\begin{array}{l}\text { Fully timber } \\
\text { construction }\end{array}$ & $\begin{array}{l}\text { Fully timber } \\
\text { construction }\end{array}$ & $\begin{array}{l}\text { Fully timber } \\
\text { construction }\end{array}$ & $\begin{array}{l}\text { Fully timber } \\
\text { construction }\end{array}$ \\
\hline $\begin{array}{l}\text { Solid waste } \\
\text { management }\end{array}$ & $\begin{array}{l}\text { Fishing net as } \\
\text { a hammock } \\
\text { Curtain for } \\
\text { decoration } \\
\text { Dead shells } \\
\text { as table } \\
\text { ashtray } \\
\text { Recycling of } \\
\text { cooking oil }\end{array}$ & $\begin{array}{l}\text { WC, } \\
\text { Wash basin } \\
\text { and dead } \\
\text { shells as plant } \\
\text { pots } \\
\text { Wine bottles } \\
\text { as decoration } \\
\text { Composting } \\
\text { Reuse bottles } \\
\text { Tree trunks- } \\
\text { signage's } \\
\text { Recycling of } \\
\text { aluminium } \\
\text { cans } \\
\text { Recycling of } \\
\text { cooking oil }\end{array}$ & $\begin{array}{l}\text { Music } \\
\text { records and } \\
\text { dead corals as } \\
\text { decoration } \\
\text { Fishing net as } \\
\text { canopy and } \\
\text { hammock } \\
\text { Wine bottles } \\
\text { for landscape } \\
\text { Boat ropes, } \\
\text { Coconut } \\
\text { husks as } \\
\text { flower pots } \\
\text { Plastic bottles } \\
\text { as bulb } \\
\text { holder } \\
\text { Recycling of } \\
\text { cans and oil } \\
\end{array}$ & $\begin{array}{l}\text { Water } \\
\text { dispenser } \\
\text { Recycling } \\
\text { of } \\
\text { aluminium } \\
\text { cans } \\
\text { Paperless } \\
\text { technology }\end{array}$ & $\begin{array}{l}\text { Recycling of } \\
\text { aluminium } \\
\text { cans } \\
\text { Recycling of } \\
\text { cooking oil } \\
\text { Reuse of food } \\
\text { container }\end{array}$ & $\begin{array}{l}\text { Boat rope as } \\
\text { railing } \\
\text { Stones as } \\
\text { restaurant } \\
\text { table marker } \\
\text { Recycling of } \\
\text { cans } \\
\text { Reuse of } \\
\text { cooking oil }\end{array}$ \\
\hline $\begin{array}{l}\text { Sewage } \\
\text { management }\end{array}$ & $\begin{array}{l}\text { Overflow } \\
\text { sewage pump } \\
\text { to forest bed }\end{array}$ & $\begin{array}{l}\text { Good quality } \\
\text { septic tank }\end{array}$ & $\begin{array}{l}\text { Good quality } \\
\text { septic tank }\end{array}$ & $\begin{array}{l}\text { Overflow } \\
\text { sewage } \\
\text { pump to } \\
\text { forest bed }\end{array}$ & $\begin{array}{l}\text { Overflow } \\
\text { sewage pump } \\
\text { to forest bed }\end{array}$ & $\begin{array}{l}\text { Good } \\
\text { quality } \\
\text { septic tank }\end{array}$ \\
\hline
\end{tabular}




\begin{tabular}{|c|c|c|c|c|c|c|}
\hline $\begin{array}{l}\text { Freshwater } \\
\text { management }\end{array}$ & $\begin{array}{l}\text { Water saving } \\
\text { reminder }\end{array}$ & $\begin{array}{l}\text { Rainwater } \\
\text { harvesting } \\
\text { Water saving } \\
\text { reminder }\end{array}$ & $\begin{array}{l}\text { Rainwater } \\
\text { harvesting } \\
\text { Water saving } \\
\text { reminder }\end{array}$ & $\begin{array}{l}\text { Water } \\
\text { saving } \\
\text { reminder }\end{array}$ & $\begin{array}{l}\text { Water saving } \\
\text { reminder }\end{array}$ & $\begin{array}{l}\text { Dual flush } \\
\text { WC }\end{array}$ \\
\hline \begin{tabular}{l} 
Ventilation\} $\\
{\text { Indoor }} \\
{\text { Environmen }} \\
{\text { tal Quality }}$ & $\begin{array}{l}\text { Roof } \\
\text { openings } \\
\text { Adequate } \\
\text { windows } \\
\text { Full height } \\
\text { sliding door }\end{array}$ & $\begin{array}{l}\text { No air-cond } \\
\text { Open balcony } \\
\text { Adequate } \\
\text { window }\end{array}$ & $\begin{array}{l}\text { No air-con } \\
\text { Adequate } \\
\text { window } \\
\text { Open } \\
\text { corridor and } \\
\text { balcony }\end{array}$ & $\begin{array}{l}\text { No air-con } \\
\text { Open } \\
\text { balcony } \\
\text { Adequate } \\
\text { windows } \\
\text { and } \\
\text { openings }\end{array}$ & $\begin{array}{l}\text { Adequate } \\
\text { windows and } \\
\text { openings }\end{array}$ & $\begin{array}{l}\text { Adequate } \\
\text { windows } \\
\text { Air- cond }\end{array}$ \\
\hline $\begin{array}{l}\text { Visual } \\
\text { amenity } \\
\text { Element } \\
\end{array}$ & $\begin{array}{l}\text { Wooden } \\
\text { blind }\end{array}$ & $\begin{array}{l}\text { Louver } \\
\text { windows }\end{array}$ & $\begin{array}{l}\text { Elevated } \\
\text { room }\end{array}$ & $\begin{array}{l}\text { Timber } \\
\text { louver } \\
\text { windows } \\
\end{array}$ & $\begin{array}{l}\text { Casement } \\
\text { windows and } \\
\text { curtain }\end{array}$ & $\begin{array}{l}\text { Louver } \\
\text { windows } \\
\text { and curtain } \\
\end{array}$ \\
\hline $\begin{array}{l}\text { Noise } \\
\text { control }\end{array}$ & In control & No Bar & In control & No Bar & In control & In control \\
\hline $\begin{array}{l}\text { Energy } \\
\text { management }\end{array}$ & $\begin{array}{l}\text { Energy } \\
\text { saving bulb } \\
\text { Key card } \\
\text { Natural } \\
\text { drying } \\
\text { Light of } \\
\text { No TV and } \\
\text { Iron }\end{array}$ & $\begin{array}{l}\text { No air- } \\
\text { conditioners } \\
\text { Energy } \\
\text { saving bulb } \\
\text { Energy } \\
\text { saving } \\
\text { stickers } \\
\text { Natural } \\
\text { drying }\end{array}$ & $\begin{array}{l}\text { No air- } \\
\text { conditioners } \\
\text { Energy } \\
\text { saving bulb } \\
\text { Natural } \\
\text { drying } \\
\text { No TV and } \\
\text { iron }\end{array}$ & $\begin{array}{l}\text { No air- } \\
\text { conditioners } \\
\text { Energy } \\
\text { saving bulb } \\
\text { Natural } \\
\text { drying } \\
\text { No TV and } \\
\text { iron }\end{array}$ & $\begin{array}{l}\text { Energy saving } \\
\text { bulb } \\
\text { Natural drying } \\
\text { No TV and } \\
\text { iron } \\
\text { Light of when } \\
\text { unused }\end{array}$ & $\begin{array}{l}\text { Light of } \\
\text { when } \\
\text { unused } \\
\text { Energy } \\
\text { saving bulb } \\
\text { No TV and } \\
\text { iron }\end{array}$ \\
\hline $\begin{array}{l}\text { Pollutants } \\
\text { Control } \\
\text { Management }\end{array}$ & $\begin{array}{l}\text { No carpet } \\
\text { Green paint } \\
\text { Roof ceiling }\end{array}$ & $\begin{array}{l}\text { No carpet } \\
\text { Green paint } \\
\text { No air-cond } \\
\text { Roof ceiling }\end{array}$ & $\begin{array}{l}\text { No air-cond } \\
\text { No carpet } \\
\text { Roof ceiling }\end{array}$ & $\begin{array}{l}\text { No air-cond } \\
\text { No carpet } \\
\text { Roof ceiling }\end{array}$ & $\begin{array}{l}\text { No carpet } \\
\text { Roof ceiling }\end{array}$ & $\begin{array}{l}\text { No carpet } \\
\text { Roof ceiling }\end{array}$ \\
\hline
\end{tabular}
\end{tabular}

(Source: Author)

\subsection{Conclusion}

The findings have shown that there are various kinds of environmental practices adopted by the chalet operators and most of the environmental practices are similar on both islands. Only one difference was identified. The difference was in terms of solid waste management. Structured observation of the islands has shown that Kapas Island is cleaner compared to the Tioman Island. Less solid waste is found on the Island compared to the Tioman Island. The finding also shows that the Kapas Island operators are greener than Tioman operators. They adopted more environmental practices in their operation compared to the Tioman operators. The most important finding is creative and educated operators can introduce new environmental practices, which able to reduce waste, energy, water and pollution. This study outcome is adding knowledge to a growing body of literature on the environmental practices. This study suggested that more environmental practices should be informed to the SICs operators in Malaysia for the improvement of the quality of life of the peoples and environment. 


\section{Acknowledgement}

This research is self-funded and partially funded by Ministry of Higher Education Malaysia. This research is a part of corresponding author's PhD study at the Universiti Teknologi Malaysia, Shah Alam.

\section{References}

A. Enz, C., \& A.Siguaw, J. (1999). Best hotel environmental practices. Cornell Hotel and Restaurant Administration Quarterly, 40 (5), 72-77.

Alonso, A. D., \& Ogle, A. (2010). Tourism and hospitality small and medium enterprises and environmental sustainability. Management Research Review, 33 (8), 818-826. doi:10.1108/01409171011065626

Antweiler, C. (2007). Globalization challenges for small island developing states.

Ayala, H. (1995). Ecoresort: Industry Hana Ayala a "green" master plan for the international resort industry. International Journal of Hospitality Management, 14 (3), 351-374.

Baysan, S. (2001). Perceptions of the environmental impacts of tourism: A comparative study of the attitudes of German, Russian and Turkish tourists in Kemer, Antalya. Tourism Geographies, 3 (2), 218-235. doi:10.1080/14616680010030284

Bohdanowicz, P. (2005). European Hoteliers environmental attitudes greening the business. Cornell Hotel and Restaurant Administration Quarterly, 46, 188-204. doi:10.1177/0010880404273891

Chan, E. S. ., \& Wong, S. C. . (2006). Motivations for ISO 14001 in the hotel industry. Tourism Management, 27, 481-492. doi:10.1016/j.tourman.2004.10.007

Erdogan, N., \& Baris, E. (2007). Environmental protection programs and conservation practices of hotels in Ankara, Turkey. Tourism Management, 28, 604-614. doi:10.1016/j.tourman.2006.07.003

George I, K., \& Andreas C, S. (2003). Greening The service Profit Chain: The Impact Of Environmental Management Practices. Production and Operations Management, 12 (3), 386-403.

Goodman, A. (2000). Implementing Sustainability in Service Operations at Scandic Hotels. Interfaces. doi:10.1287/inte.30.3.202.11653

Gunn, \& C.A. (1998). Vacationscapes: Designing tourist regions. (Van Nostrand Reinhold, Ed.). New York.

Inskeep, E. (1987). Environmental planning for tourism. Annals of Tourism Research, 14 (1), 118-135. doi:10.1016/0160-7383(87)90051-X

Jackson, L. A. (2010). Toward a framework for the components of green lodging. Journal of Retail \& Leisure, Property, 9 (3), 211-230. doi:10.1057/rlp.2010.6

Jamaludin, M., \& Yusof, Z. B. (2013). Best Practice of Green Island Resorts. Procedia - Social and Behavioral Sciences, 105, 20-29. doi:10.1016/j.sbspro.2013.11.003 
Yusof, Z.B., \& Jamaludin, M. / Asian Journal of Quality of Life, AjQoL, 2(8) Oct / Dec 2017 (p.1-12)

Kreidler Nicole Bieak. (2010). An Examination of Green Environmental Attributes in Hotel Service Settings. Auburn Alabama University.

Li, G., Yang, X., Liu, Q., \& Zheng, F. (2014). Destination island effects: A theoretical framework for the environmental impact assessment of human tourism activities. Tourism Management Perspectives, 10, 11-18. doi:10.1016/j.tmp.2013.12.001

Manaktola, K., \& Jauhari, V. (2007). Exploring consumer attitude and behavior towards green practices in the lodging industry in India. International Journal of Contemporary Hospitality Management, 19 (5), 364-378. doi:10.1108/09596110710757534

Mason, P. (2011). Environmental impacts of tourism. In Tourism Impacts Planning and Management (pp. 69-84). doi:DOI: 10.1016/B978-0-7506-5970-3.50010-5

McKercher, B. (1993). Some fundamental truths about tourism: understanding tourism's social, and environmental impacts. Journal of Sustainable Tourism, 1, 6-16.

Mensah, I. (2007). Environmental management and sustainable tourism development: The case of hotels in Greater Accra Region (GAR) of Ghana. Journal of Retail and Leisure Property, 6, 15-22. doi:10.1057/palgrave.rlp.5100039

Millar, M., \& Baloglu, S. (2011). Hotel Guest's preferences for green room attributes. Cornell Hospitality Quarterly, 52 (3), 302-311. doi:10.1177/1938965511409031

Molina-Azorín, J. F., Claver-Cortés, E., Lopez-Gamero, M. D., \& Tarí, J. J. (2009). Green management and financial performance: A literature review. Management Decision, 47 (7), 1080-1100. doi:10.1108/00251740910978313

Nabiha, A. k. siti, R.A, G., Wahid, N. A., Amran, A., I. Abustan, \& R. Mahadi. (2011). A Field Survey of Environmental Initiatives at Selected Resorts in Malaysia. World Applied Science Journal, 12 (Special issue of Tourism \& Hospitality), 56-63.

Nicholls, S., \& Kang, S. (2012). Green initiatives in the lodging sector: Are properties putting their principles into practice? International Journal of Hospitality Management, 31, 609-611. doi:10.1016/j.jijhm.2011.10.010

Rahman, I., Reynolds, D., \& Svaren, S. (2012). How "green" are North American hotels? An exploration of low-cost adoption practices. International Hospitality Management, 31, 720-727. doi:10.1016/j.jhm.2011.09.008

Smith, E. E., \& Perks, S. (2010). A perceptual study of the impact of green practice implementation of the business functions. Southern African Business Review, 14 (3), 1-29.

Tang, F. E. (2012). A Study of Water Consumption in Two Malaysian Resorts. World Academy of Science, Engineering and Technology, (68), 1162-1167.

Tooman, H., Sloan, P., Legrand, W., \& Fendt, J. (2009). Case studies of best practices in sustainability in German and Estonian Hotels.

Yusof, Z. B., \& Jamaludin, M. (2013). Green Approaches of Malaysian Green Hotels and Resorts. Procedia Social and Behavioral Sciences, 85, 421-431. doi:10.1016/j.sbspro.2013.08.371 